\title{
Influence of Social Mechanisms on Innovation Behaviour of Actors in Agricultural Innovation Platforms in Uganda https://dx.doi.org/10.4314/jae.v23i3.2
}

\section{Turyahikayo Willy}

Department of Economics, Makerere University Business School. P.O Box 1337, Kampala,

Uganda. Email: wturyahikayo@mubs.ac.ug Tel: +256772957295

\section{Matsiko B. Frank}

Department of Extension and Innovation Studies, Makerere University. P.O Box 7062, Kampala, Uganda. Email:fbmatsiko@gmail.com Tel: +256772960191

\section{Okiror J. John}

Department of Extension and Innovation Studies, Makerere University. P.O Box 7062, Kampala, Uganda. Email: okiror2010@gmail.com Tel: +256 772899644

\section{Obaa B. Bernard}

Department of Extension and Innovation studies, Makerere University. P.O Box 7062, Kampala, Uganda. Email: obaaben@gmail.com Tel: +256772660006

\section{Hanf J. Habil}

Economic Programs and the Chair of International Marketing Management at Geisenheim University, Germany.von-lade-st.1 D-65366, Geisenheim. Email: jon.hanf@hs-gm.de

\begin{abstract}
This study employed network governance theory to examine the intermediate social processes that lead to actor innovation behaviour in an agricultural innovation platform. Using a sample of 319 randomly selected farmers and key informant interviews, it was established that the direct effect of social mechanisms such as restricted access, collective sanctions, macro cultures and reputation on innovation behaviour was negative $(\beta=-0.050)$ and insignificant implying that as networks put in place stringent rules and regulations, actors in an innovation network tend to withdraw from platform activities. However, the effect was positive and significant through adaptation $(\beta=0.697)$, coordination $(\beta=0.121)$ and safeguard of exchanges $(\beta=0.418)$. This therefore means that for social mechanisms to influence actor innovation behaviour, they must be accompanied with adaptation and coordination measures and appropriate strategies that safeguard exchanges in a network. Platform leaders should also implement activities that bring all actors together to share relevant information, mobilize resources and synchronize the timing and sequencing of activities as a means of coordination, adaptation and safeguard of exchanges. The study further recommends that to increase the rate of agricultural innovations, members of the networks should continually seek for new processes, markets, inputs and take advantage of new opportunities in their operating environment so as to be adaptive.
\end{abstract}

Key words: Innovation behaviour, innovation platforms, social mechanisms, 
Creative Commons User License: CC BY-NC-ND

Abstracted by: EBSCOhost, Electronic Journals Service (EJS),

Google Scholar, Journal Seek, Scientific Commons,

Food and Agricultural Organization (FAO), CABI and Scopus

http://eoi.citefactor.org/10.11226/v23i3
Journal of Agricultural Extension

Vol. 23 (3) July, 2019

ISSN(e): 24086851; ISSN(Print); 1119944X

http://journal.aesonnigeria.org

http://www.ajol.info/index.php/jae

Email: editorinchief@aesonnigeria.org

\section{Introduction}

Innovation platforms are being used as a dynamic mechanism that involves farmers and diverse service providers who interact for knowledge generation, sharing and diffusion for purposes of social learning (Cullen, Josephine, Katherine, Zelalem \& Alan, 2014). From the agricultural context, an innovation platform is as a forum for learning and action involving a group of actors with different backgrounds and interests: farmers, agricultural input suppliers, traders, food processors, researchers, government officials and NonGovernmental Organizations who come together to identify common challenges and develop common ways to mitigate them through social learning (Homann-Kee Tui, Adekunle, Lundy, Tucker, Birachi, Schut, \& Mundy, 2013). The use of innovation platforms in agriculture is premised on the assumption that by bringing together various actors, innovation platforms are able to identify and address existing challenges to innovation among the stakeholders (Swaans, Puskur \& Haile, 2013).

Innovation platforms are part of wider participatory approaches that were promoted since the mid-1980s as a means of implementing the agricultural innovation systems (Cullen, et al., 2014). An agricultural innovation system is a network of different stakeholders from farmers, research, extension, policy, and markets focused on bringing new products, new processes, and new forms of organization into economic use, together with the institutions and policies that affect their innovation behavior and performance (Dimelu, Enwelu, Attah, \& Emodi 2014; Saravanan \& Suchiradipta, 2017). It is a systematic, interactive and evolutionary approach where individuals, networks or organizations, together with the institutions and policies influence innovative behaviors and performance of the economic and social life (Schut, Rodenburg, Klerkx, van Ast, \& Bastiaans, 2014). Other scholars such as Kilelu, Klerkx \& Leeuwis (2013) argue that the agricultural innovation systems approach emphasizes the collective nature of innovation and stresses that innovation is a co-evolutionary process that should align technical, social, institutional and organizational dimensions. Interventions in commodity innovations are therefore increasingly redirecting their attention toward setting up innovation platforms and networks, as mechanisms for operationalizing agricultural innovation systems.

Innovation platforms are considered to be social networks and informal partnerships that are guided by informal social systems rather than by bureaucratic structures and formal contractual relationships. Because of this characteristic, they are seen as a promising avenue for finding solutions to complex social, economic and environmental challenges that face agricultural innovation stakeholders such as farmers, development practitioners and policymakers (Sartas, 2018; Kilelu et al., 2013). It is argued that innovation platforms increase collaboration, exchange of knowledge and influence mediation among multiple actors thereby enhancing their capacity to innovate and scale up the actor innovation behaviour (Hermans, Sartas, van Schagen, van Asten \& Schut, 2017). Innovation behaviour is a multi-dimensional concept that refers to the sum of all work activities carried out by individuals during an innovation process. Other scholars argue that it is a knowledge management process that involves recognizing a problem, creating solutions for the problem and creating support for the solutions (Messmann \& Mulder, 2012). In the context of agricultural innovations, innovation behaviour involves all activities from the 
Creative Commons User License: CC BY-NC-ND

Abstracted by: EBSCOhost, Electronic Journals Service (EJS),

Google Scholar, Journal Seek, Scientific Commons,

Food and Agricultural Organization (FAO), CABI and Scopus

http://eoi.citefactor.org/10.11226/v23i3
Journal of Agricultural Extension

Vol. 23 (3) July, 2019

ISSN(e): 24086851; ISSN(Print); 1119944X

http://journal.aesonnigeria.org

http://www.ajol.info/index.php/jae

Email: editorinchief@aesonnigeria.org

generation of new ideas to their implementation such as use of improved varieties, improved agronomic practices, appropriate post-harvest technologies and value addition along the supply chain.

Although innovation platforms are seen as a potential tool for addressing coordination and communication between stakeholders, they often provide an imperfect negotiation process due to challenges such as power imbalance and information asymmetries between actors which may hinder platforms from realizing the envisaged innovations (Swaans et al., 2013). For networks to influence the behaviour of a social system, networks work through a social mechanism. However, the role of this mechanism and how it fosters actor innovation behaviour in networks has received scanty attention in agricultural innovation studies (Ayele, Duncan \& Khanh 2012). This paper examined the effect of social mechanisms such as norms, values, beliefs, restrictions on entry and exit, skills and character of actors on actor innovation behaviour in Uganda.

\section{Theoretical framework}

The study was anchored on the network governance theory by Jones, Hesterley \& Borgatti (1997) to explain how social mechanisms influence actor innovation behaviour. The theory is a synthesis of transaction cost theory and social network analysis. According to the transaction cost theory, network governance is a result of demand uncertainty, asset specificity, complex tasks, and frequent exchanges among the actors. These exchange conditions drive firms towards structural and relational embeddedness. It is this embeddedness that acts as a conduit for social mechanisms to adapt, coordinate and safeguard the transaction cost exchanges. Social mechanisms are the institutional mechanisms of restricted access to action arena, collective sanctions, macro-cultures and reputation that help to control the behaviour of the social system and its components (Jones et al., 1997). Restricted access to exchanges in the network is a reduction in the number of actors within the social network (Jones et al., 1997). Restrictions on the action arena reduces coordination costs by having fewer partners who interact more often and allows actors to learn about each other and to establish routines for working together thereby maintaining coherence of the social system. It also facilitates quick identification among the actors which helps create strong ties among them (Turyahikayo, Matsiko, Okiror \& Buregyeya, 2017). Restricted access is done for either status maximization or relational contracting. Under status maximization, the network tries to avoid actors with a lower status whereas relational contracting is where networks tend to work with fewer partners so as to reduce coordination and management costs. In both cases, a restriction on access to the action arena is premised on the fact that it reduces costs thereby determining the performance of the network. Collective sanctions on the other hand are all those punishments given to members of the network who violate norms, values or goals of the network. This may involve ostracism or exclusion from the network for either short periods or indefinitely so as to maintain the positive performance of the social system (Jones et al., 1997). Collective sanctions define acceptable behaviour by demonstrating the consequences of non-compliance to the rules in the network.

Macro-culture is a system of widely shared values and norms that guide actions and create specific behaviours among the actors in a network (Jones et al., 1997). The value 
Creative Commons User License: CC BY-NC-ND

Abstracted by: EBSCOhost, Electronic Journals Service (EJS),

Google Scholar, Journal Seek, Scientific Commons,

Food and Agricultural Organization (FAO), CABI and Scopus

http://eoi.citefactor.org/10.11226/v23i3
Journal of Agricultural Extension

Vol. 23 (3) July, 2019

ISSN(e): 24086851; ISSN(Print); 1119944X

http://journal.aesonnigeria.org

http://www.ajol.info/index.php/jae

Email: editorinchief@aesonnigeria.org

and norms are shared by all members of the network and they specify the roles, rolerelationship and the generally accepted approaches for solving complex problems in the network. Due to approaches that are accepted by all actors, macro-culture facilitates efficient exchange among actors and enhances coordination among them through socialization which allows accomplishment of complex routines and information flow for the continued performance of the network (Turyahikayo, et al., 2017). Reputation on the other hand refers to the actor's character, skills, reliability and dependability attributes that are important to safeguard exchanges. These attributes are particularly important because actors often have imperfect information about the behaviours of other actors. Thus, the presence of these attributes helps to deter deceptive behaviour, which enhances cooperation, adaptation and safeguard of exchanges which are key issues in assessing the effectiveness of social mechanisms (Jones et al., 1997). Reputable actors with successful past performances tend to move ahead of their counterparts and encourage actor innovativeness. The central thesis of the theory is that the use of social mechanisms facilitates adaptation, coordination and safeguard of exchanges and this will have a bearing on actor behaviour.

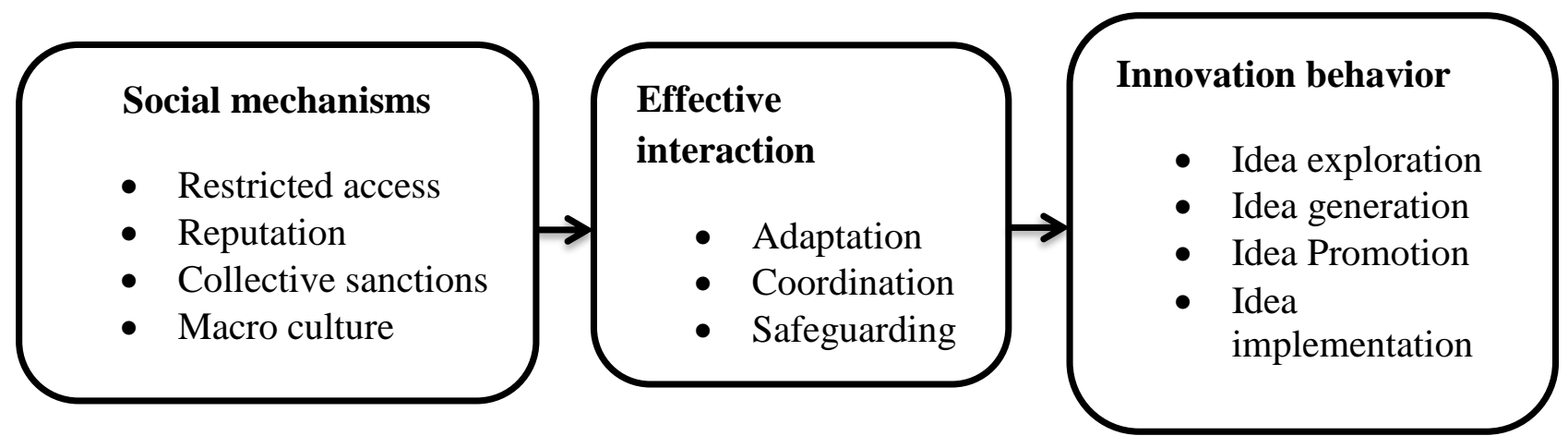

Figure 1: The conceptual model of social mechanism and innovation behavior

Source: Adapted from network governance theory with modification, 2017

\section{Methodology}

A cross sectional survey design was used in this study. Based on the diverse activities along the value chain in the maize and soy bean production, the Kiboga-Kyankwanzi innovation platform in central Uganda was selected purposively. The IP also has a wide membership in terms of gender and heterogeneity in actors. Kiboga-Kyankwanzi innovation platform (IP) was imitated in February 2014 by Humid Tropics with the ultimate aim of changing the lives of the rural farmers in the two districts of Kiboga and Kyankwanzi through adoption of high yielding varieties. The study population was all members of the IP who include farmers, private business sector, researchers, non-governmental organization, IP executive committee members, farmer group leaders, local policy makers, members of training institutions and extension workers who constituted the units of observation. Since the IP stretches to two districts, a stratified sampling was used to select farmers from the two districts. One farmer group with the biggest registered farmers was purposively selected from each district. In Kyankwanzi district, Tukolele wamu group with a population of 486 farmers was selected whereas Twezimbe with a population of 
Creative Commons User License: CC BY-NC-ND

Abstracted by: EBSCOhost, Electronic Journals Service (EJS), Google Scholar, Journal Seek, Scientific Commons,

Food and Agricultural Organization (FAO), CABI and Scopus

http://eoi.citefactor.org/10.11226/v23i3
Journal of Agricultural Extension

Vol. 23 (3) July, 2019

ISSN(e): 24086851; ISSN(Print); 1119944X

http://journal.aesonnigeria.org

http://www.ajol.info/index.php/jae

Email: editorinchief@aesonnigeria.org

262 farmers was selected in Kiboga. Lists of registered farmers were obtained from the IP leadership. A sample size of 214 and 155 farmers were determined from Tukolele wamu and Twezimbe farmer groups respectively using Krejcie and Moran (1970). Simple random sampling was then used to select the farmers. The overall response rate in the two districts was $86 \%$. In Kyankwanzi district, one hundred eighty-nine (189) answered the questionnaire while one hundred and thirty (130) answered in Kiboga representing $88 \%$ and $84 \%$ respectively. Positional purposive selection was used to select IP executive committee members, private business operators, researchers, NGOs, IP chairpersons, local policy makers, training institutions and farmer group leaders. This triangulation helped to improve on the validity and reliability of instruments.

\section{Measurement, data collection and analysis}

To determine the effect of social mechanisms and the mediation effect of interaction effects of adaptation, coordination and safeguard of exchanges on actor innovation behaviour, regression analysis was performed using the structural equation model (SEM). Social mechanisms were assessed using four subscales i.e. restricted access, actor reputation, collective sanctions and macro cultures as proposed by Jones et al. (1997). Innovation behaviour was assessed using a total score of four subscales of idea exploration, generation, promotion, and implementation as used by Messmann and Mulder (2012) but with slight modifications to suit the study.

Interviewer administered questionnaire technique was used to collect quantitative data from farmers after translating the questionnaire into the local language. A questionnaire consisting of self-report items was developed to measure the social mechanisms and innovation behaviour. Consequently, multi-item scales were used to measure all constructs whose questions were put on a five point Likert-type scale (ranging from $1=$ strongly disagree to $5=$ strongly agree) to test the level of agreement. In-depth interviewing and focus group discussions were also used to collect qualitative data from other stakeholders that included IP executive committee members, private business operators, researchers, NGOs, IP chairpersons, local policy makers, training institutions and farmer group leaders so as to improve the validity and reliability of the information.

Reliability was assessed using Cronbach's Coefficient alpha in the IBM-SPSS Statistics. For validity, all items that were found to be significantly correlated with the total score of the items were retained. For Qualitative data, reliability was achieved by using more than one person to collect the data for comparison of notes. Validity on the other hand was achieved by ensuring that the intended data was actually captured and reported exactly as captured. Probing more in-depth information as well as triangulation also helped to validate data. 
Creative Commons User License: CC BY-NC-ND

Abstracted by: EBSCOhost, Electronic Journals Service (EJS),

Google Scholar, Journal Seek, Scientific Commons,

Food and Agricultural Organization (FAO), CABI and Scopus

http://eoi.citefactor.org/10.11226/v23i3
Journal of Agricultural Extension

Vol. 23 (3) July, 2019

ISSN(e): 24086851; ISSN(Print); 1119944X

http://journal.aesonnigeria.org

http://www.ajol.info/index.php/jae

Email: editorinchief@aesonnigeria.org

\section{Results and Discussion}

This section highlights key findings on the extent of social mechanisms used to foster compliance within the social system. The section further presents the relationship between these social mechanisms and actor innovation behaviour within the platform.

\section{Socio-Economic Characteristics of Respondents}

Although land is taken as an important resource especially for agriculture, an analysis of land ownership showed that the majority of the respondents were tenants $(50.2 \%)$, (Table 1). Only $5.3 \%$ of the respondents said they owned land on which they farm. It was established that the mean plot size of land was 11.9ha. However, respondents were allocating an average of 6.3 ha (about $53 \%$ ) to maize and soy bean production. This is because $72.1 \%$ of the respondents had livestock in addition to crop husbandry. This percentage is above the national average of $66.9 \%$ (UBOS, 2016). Majority of the respondents $(89.3 \%)$ were semi-commercial because they grew crops for both market and home consumption whereas only $10.7 \%$ indicated that they grow maize and soybean for only commercial purposes.

\section{Table 1: Socio-economic characteristics of respondents}

\begin{tabular}{lll}
\hline Characteristic & Category & $\%$ age \\
\hline Land ownership & Tenant & $50.2 \%$ \\
& Hired & $44.5 \%$ \\
& Self-owned & $5.3 \%$ \\
Type of farm & Crop only & $27.9 \%$ \\
\multirow{2}{*}{ Purpose of crops } & Crop and livestock & $72.1 \%$ \\
& Commercial & $10.7 \%$ \\
& Semi Commercial & $89.3 \%$ \\
\hline
\end{tabular}

Source: Field survey, 2018

\section{Innovation Behaviour and Social Mechanisms}

Most of the mean scores for the items on innovation behavior were below 3.0. (Table 2) For idea generation all items scored a mean score of 3.0 and above implying that farmers are relatively able to generate solutions to the challenges in the crop value chain as compared to exploration, promotion and implementation of new ideas in the crop value chains. The search for new forms of selling their products scored the highest mean $(\bar{x})$ 4.0 and std. dev. = 1.2). This implies that most of the farmers' innovative activities are in search of new markets for their output. As pointed out by scholars such as Adekunle \& Fatunbi (2012), Cullen et al., (2014), Innovation Platforms identify bottlenecks especially in the areas of marketing and production requirements regarding quantity, quality and the timing of sales. This possibly could explain why most of the innovations were in marketing. 
Creative Commons User License: CC BY-NC-ND

Abstracted by: EBSCOhost, Electronic Journals Service (EJS),

Google Scholar, Journal Seek, Scientific Commons,

Food and Agricultural Organization (FAO), CABI and Scopus

http://eoi.citefactor.org/10.11226/v23i3
Journal of Agricultural Extension

Vol. 23 (3) July, 2019

ISSN(e): 24086851; ISSN(Print); 1119944X

http://journal.aesonnigeria.org

http://www.ajol.info/index.php/jae

Email: editorinchief@aesonnigeria.org

Table 2: Mean response on level of innovation behaviour

\begin{tabular}{|c|c|c|c|}
\hline Items & Mean & Std. Dev. & $\begin{array}{c}\text { Cronbach's } \\
\text { Alpha }\end{array}$ \\
\hline \multicolumn{4}{|l|}{ Idea exploration } \\
\hline $\begin{array}{l}\text { I try to explore opportunities in the maize value } \\
\text { chain }\end{array}$ & 2.4 & 1.4 & \multirow{7}{*}{0.712} \\
\hline I pay attention to other people's view points & 2.5 & 1.4 & \\
\hline I try to understand the maize value chain & 2.4 & 1.4 & \\
\hline I pay attention to new and improved crop varieties & 2.4 & 1.4 & \\
\hline I pay attention to new markets for maize products & 2.4 & 1.4 & \\
\hline $\begin{array}{l}\text { I pay attention to the opportunities in the maize } \\
\text { value chain }\end{array}$ & 2.4 & 1.4 & \\
\hline $\begin{array}{l}\text { I consider new skills and information } \\
\text { Idea generation }\end{array}$ & 2.4 & 1.4 & \\
\hline I search out for new farming methods in maize & 3.1 & 1.3 & \multirow{5}{*}{0.749} \\
\hline Generating original solutions for farming problems & 3.0 & 1.5 & \\
\hline $\begin{array}{l}\text { Searching for the new forms of selling maize } \\
\text { products }\end{array}$ & 4.0 & 1.2 & \\
\hline I search out for new skills and information & 3.3 & 1.5 & \\
\hline $\begin{array}{l}\text { I have attempted to find new approaches to } \\
\text { agronomic activities in the maize value chain } \\
\text { Idea promotion }\end{array}$ & 3.2 & 1.5 & \\
\hline I mobilize support for new maize varieties & 2.4 & 1.4 & \multirow{5}{*}{0.662} \\
\hline I mobilize other members for new markets & 2.4 & 1.4 & \\
\hline $\begin{array}{l}\text { I make IP members enthusiastic for new maize } \\
\text { varieties }\end{array}$ & 2.4 & 1.4 & \\
\hline $\begin{array}{l}\text { I convince other people to use new maize } \\
\text { varieties }\end{array}$ & 2.4 & 1.4 & \\
\hline $\begin{array}{l}\text { I take time to mobilize other members to use new } \\
\text { skills and information } \\
\text { Idea implementation }\end{array}$ & 3.6 & 1.5 & \\
\hline I have used new maize varieties & 2.4 & 1.4 & \multirow{5}{*}{0.704} \\
\hline I have implemented avenues for value & 2.4 & 1.4 & \\
\hline I use new skills and information & 2.4 & 1.4 & \\
\hline $\begin{array}{l}\text { I have implemented the use of new marketing } \\
\text { channels }\end{array}$ & 2.4 & 1.4 & \\
\hline I implement new agronomic practices & 2.4 & 1.4 & \\
\hline
\end{tabular}

Field survey, 2018

\section{Social Mechanisms}

Table 3 shows that all items scored a mean $(\bar{x})$ score above 3.0 on the scale which implies that respondents perceive different social mechanisms in the platform to be relatively effective in fostering actor compliance. The reputation of other actors such as 
Creative Commons User License: CC BY-NC-ND

Abstracted by: EBSCOhost, Electronic Journals Service (EJS),

Google Scholar, Journal Seek, Scientific Commons,

Food and Agricultural Organization (FAO), CABI and Scopus

http://eoi.citefactor.org/10.11226/v23i3
Journal of Agricultural Extension

Vol. 23 (3) July, 2019

ISSN(e): 24086851; ISSN(Print); 1119944X

http://journal.aesonnigeria.org

http://www.ajol.info/index.php/jae

Email: editorinchief@aesonnigeria.org

their previous history, characters and skills scored the highest mean score (3.7179). The cronbach's alpha of 0.773 implies that the items can consistently measure the social mechanisms using the items listed since it is above 0.7 as proposed by Serena (2018).

\section{Table 3: Mean response on social mechanisms}

\begin{tabular}{|c|c|c|c|}
\hline Items & Mean & $\begin{array}{c}\text { Std. } \\
\text { Deviation }\end{array}$ & $\begin{array}{l}\text { Cronbach' } \\
\text { s Alpha }\end{array}$ \\
\hline $\begin{array}{l}\text { Rules are effective in determining who may } \\
\text { join and leave the platform }\end{array}$ & 3.3981 & 1.49047 & 0.773 \\
\hline $\begin{array}{l}\text { The sanctions in the platform ensure } \\
\text { compliance to the set rules }\end{array}$ & 3.5517 & 1.39957 & \\
\hline $\begin{array}{l}\text { The attributes of other actors such as } \\
\text { characters, skills, influence my actions in } \\
\text { the platform }\end{array}$ & 3.7179 & 1.41489 & \\
\hline $\begin{array}{l}\text { The members of the platform respect the } \\
\text { norms and beliefs of the platform }\end{array}$ & 3.2727 & 1.49556 & \\
\hline $\begin{array}{l}\text { The actions of the actors are guided by } \\
\text { goals and values of the platform }\end{array}$ & 3.5956 & 1.43719 & \\
\hline
\end{tabular}

Source: Field survey, 2018

\section{Effect of Social Mechanisms on Innovation Behaviour.}

Table 4 shows that except for restricted access. $(r=0.129 ; p \leq 0.05)$ the correlations between social mechanisms and innovation behaviour were insignificant $(p \geq 0.05)$ for collective sanctions, reputation and macro cultures. Although collective sanctions spell out the consequences of non-compliance with the rules in the network, these results imply that actors tend to prefer informal and voluntary entry and exit from the innovation networks. As re-echoed by one participant in the FGD.

"There are rules in our platform but we don't like them. First of all, we did not participate in making them and we are also suspicious about the fines whenever we break them. I would want a platform to have flexible rules since we are all mature people...." (Respondent, July $10^{\text {th }}$ 2017). These findings concur with a number of scholars such as Cullen et al. (2014), Schut et al. (2014) who also show that innovation networks are shaped and guided by interactions between actors and institutions that are informal and noncontractual in nature. Therefore, as rules and regulations become more stringent and formal, actors tend to either withdrawal from innovative activities in the platform or withdrawing their membership. The positive and significant correlation between restrictions on access and actor innovation behaviour implies that as actors perceive that there are controls in entry of other actors, they participate in innovative activities in the crop value chain. On one FGD, when asked why the network may restrict entry and have a limited number, one actor said:

"When we allow a limited number of members, we are able to coordinate ourselves and meet regularly. This helps us to access inputs and information about markets and other opportunities like trainings and workshops to improve our crops. When we allow all 
Creative Commons User License: CC BY-NC-ND

Abstracted by: EBSCOhost, Electronic Journals Service (EJS), Google Scholar, Journal Seek, Scientific Commons,

Food and Agricultural Organization (FAO), CABI and Scopus

http://eoi.citefactor.org/10.11226/v23i3
Journal of Agricultural Extension

Vol. 23 (3) July, 2019

ISSN(e): 24086851; ISSN(Print); 1119944X

http://journal.aesonnigeria.org

http://www.ajol.info/index.php/jae

Email: editorinchief@aesonnigeria.org

farmers to be in one group, it becomes hard to coordinate members for meetings. Instead it is better to have at least 30 members. Other members also combine to form their own group............" (Respondent, July 10 ${ }^{\text {th }} 2017$ ).

This means that having a few members improves on coordination and adaptation to the new marketing environment. This is in conformity with Andres, Mandloi and Bhullar (2016) who have previously argued that working with a restricted number of actors is appropriate since it enables actors to meet quite often and develop strong ties at firm level experimentation. Such scholars have argued that having a limited number of actors in a network not only reduces the costs of coordination but also increases the status of the network.

Table 4: Correlation between social mechanisms and innovation behavior

\begin{tabular}{|c|c|c|c|c|c|c|c|}
\hline \multirow{6}{*}{ rho } & & & 1 & 2 & 3 & 4 & 5 \\
\hline & Restricted access & $\begin{array}{l}\text { Correlation Coefficient } \\
\text { Sig. (2-tailed) }\end{array}$ & 1.000 & & & & \\
\hline & Collective sanctions & $\begin{array}{l}\text { Correlation Coefficient } \\
\text { Sig. (2-tailed) }\end{array}$ & $\begin{array}{r}.366^{\star \star} \\
.000\end{array}$ & 1.000 & & & \\
\hline & Reputation & $\begin{array}{l}\text { Correlation Coefficient } \\
\text { Sig. (2-tailed) }\end{array}$ & $\begin{array}{r}.638^{* *} \\
.000\end{array}$ & $\begin{array}{r}.458^{* *} \\
.000\end{array}$ & 1.000 & & \\
\hline & Macro cultures & $\begin{array}{l}\text { Correlation Coefficient } \\
\text { Sig. (2-tailed) }\end{array}$ & $\begin{array}{r}.532^{* \star} \\
.000\end{array}$ & $\begin{array}{r}.345^{* *} \\
.000\end{array}$ & $\begin{array}{r}.641^{* *} \\
.000\end{array}$ & 1.000 & \\
\hline & Innovation behavior & $\begin{array}{l}\text { Correlation Coefficient } \\
\text { Sig. (2-tailed) }\end{array}$ & $\begin{array}{r}.129^{*} \\
.021\end{array}$ & $\begin{array}{r}-.052 \\
.356\end{array}$ & $\begin{array}{l}.035 \\
.530\end{array}$ & $\begin{array}{l}.029 \\
.606\end{array}$ & 1.000 \\
\hline
\end{tabular}

Source: Field survey, 2018

To fully understand the effect of social mechanisms on actor innovation behaviour, a regression was performed using the structural equation modeling (SEM). The results show that the relationship between the social mechanisms and actor innovation behaviour is negative and insignificant $(\beta=-0.050)$. Results from both the correlations and regression analysis imply that actors' willingness to participate in innovative activities reduces as actors perceive that there are strong rules and punishments against noncompliance with norms, values and goals. These findings are in line with Cullen et al. (2014) who argue that innovation platforms are informal partnerships that are guided by informal social systems rather than by bureaucratic structures and formal contractual relationships. Other scholars such as Schut et al. (2014) have also asserted that innovations are shaped by interactions between actors and institutions that should be guided by mutual benefits, trust, and reciprocity rather than contractual and legal frameworks. This again means that actors would wish to participate in networks where there are no strict laws against non-compliance. 
Creative Commons User License: CC BY-NC-ND

Abstracted by: EBSCOhost, Electronic Journals Service (EJS),

Google Scholar, Journal Seek, Scientific Commons,

Food and Agricultural Organization (FAO), CABI and Scopus

http://eoi.citefactor.org/10.11226/v23i3
Journal of Agricultural Extension

Vol. 23 (3) July, 2019

ISSN(e): 24086851; ISSN(Print); 1119944X

http://journal.aesonnigeria.org

http://www.ajol.info/index.php/jae

Email: editorinchief@aesonnigeria.org

Table 5: Relationship between social mechanisms and innovation behaviour.

\begin{tabular}{|c|c|c|c|c|c|c|c|}
\hline & & Coef. & Std.Err. & $z$ & $P>Z$ & $\begin{array}{r}{\left[95^{\circ}\right.} \\
\text { Int }\end{array}$ & $\begin{array}{l}\text { Conf. } \\
\text { rval] }\end{array}$ \\
\hline Adaptation & $<-$ & & & & & & \\
\hline & $\begin{array}{l}\text { Social } \\
\text { mechanism }\end{array}$ & 0.697 & 0.045 & 15.490 & 0.000 & 0.609 & 0.785 \\
\hline & cons & 4.867 & 0.806 & 6.040 & 0.000 & 3.286 & 6.447 \\
\hline Coordination & $<-$ & & & & & & \\
\hline & $\begin{array}{l}\text { Social } \\
\text { mechanism }\end{array}$ & 0.121 & 0.042 & 2.890 & 0.004 & 0.039 & 0.202 \\
\hline & _cons & 7.882 & 0.747 & 10.550 & 0.000 & 6.418 & 9.347 \\
\hline Safeguard & $<-$ & & & & & & \\
\hline & $\begin{array}{l}\text { Social } \\
\text { mechanism }\end{array}$ & 0.418 & 0.053 & 7.950 & 0.000 & 0.315 & 0.521 \\
\hline & _cons & 10.042 & 0.943 & 10.650 & 0.000 & 8.194 & 11.889 \\
\hline Innovation & $<-$ & & & & & & \\
\hline & Adaptation & 0.297 & 0.146 & 2.030 & 0.042 & 0.010 & 0.583 \\
\hline & Coordination & -0.113 & 0.165 & -0.690 & 0.493 & -0.436 & 0.210 \\
\hline & Safeguard & -0.187 & 0.135 & -1.390 & 0.164 & -0.451 & 0.077 \\
\hline & $\begin{array}{l}\text { Social } \\
\text { mechanism }\end{array}$ & -0.050 & 0.138 & -0.360 & 0.720 & -0.320 & 0.221 \\
\hline & cons & 66.279 & 2.222 & 29.830 & 0.000 & 61.924 & 70.634 \\
\hline
\end{tabular}

Source: Field survey, 2018

However, results from the regression model indicate that the relationship between innovation behaviour and social mechanisms such as restrictions on access, reputation, macro cultures and collective sanctions is positive and significant through adaptation $(\beta=0.697)$, coordination $(\beta=0.121)$, and safeguard of exchanges $(\beta=0.418)$. (Table 5$)$. This means that having reputable actors, goals and beliefs as well as controls on entry is not enough for innovativeness in the platform. There is need to have adaptation measures through continually identifying and finding solutions to new challenges in the agricultural value chain and organize the implementation of activities that bring stakeholders together to share relevant information. These results also show that there is a need to safeguard the availability, accessibility and utilization of markets, resources and information. The roles of adaptation and coordination have been cited previously as important prerequisites for social mechanisms to influence behaviour. Specifically, restrictions on access to the network reduces the coordination costs thereby allowing implementation of activities that bring stakeholders together to share relevant information and synchronize the timing and sequencing of activities. This concurs with Andres, Mandloi and Bhullar (2016) who argue that restrictions on access in a network reduces coordination costs since it allows fewer actors who interact more often to reduce their 
Creative Commons User License: CC BY-NC-ND

Abstracted by: EBSCOhost, Electronic Journals Service (EJS),

Google Scholar, Journal Seek, Scientific Commons,

Food and Agricultural Organization (FAO), CABI and Scopus

http://eoi.citefactor.org/10.11226/v23i3
Journal of Agricultural Extension

Vol. 23 (3) July, 2019

ISSN(e): 24086851; ISSN(Print); 1119944X

http://journal.aesonnigeria.org

http://www.ajol.info/index.php/jae

Email: editorinchief@aesonnigeria.org

differences in expectations, skills and goals. The significance of exchange safeguard is also supported by Turyahikayo, et al., (2017) who argue that restricted access increases actor identification and provides fertile conditions for developing strong ties among the actors in the network.

Macro cultures such as norms, values, beliefs and goals were found to influence actor innovation behaviour. This was because of their capacity to specify role-relationships and enhance coordination. As found out by Schut et al., (2016b), values, attitudes and self coordination coordinate interdependent activities among independent entities to accomplish complex tasks by creating similar expectations and developing a common language. The results further are in line with Jones et al. (1997) who argue that collective sanctions safeguard exchanges since they define and reinforce acceptable norms, values, goals and beliefs by demonstrating the consequences of violating them.

There was also a significant effect of the actors' character, skills, reliability and dependability attributes on actor innovation behaviour. This was particularly important because actors often had imperfect information about the prevailing conditions in the crop value chain. Therefore, the presence of these attributes by actors helped to enhance cooperation, adaptation and safeguard of exchanges. As noted by Jones et al. (1997), reputable actors with successful past performances tend to move ahead of their counterparts, encourage coordination and actor innovativeness.

\section{Conclusion and Recommendations}

The use of social mechanisms helps to adapt, coordinate and safeguard exchanges in a network, which is only an intermediate process that should provide greater insight into what happens to actor behaviours especially in an innovation network. Whereas social mechanisms are significant in influencing innovativeness among multi stakeholder platforms, the intermediate mechanisms that involve adaptation and coordination of network activities are critical. For internal social mechanisms to be effective, they should be accompanied with proper coordination for markets and information. The platform ought to be adaptable to the outside environment by way of identifying and finding solutions to new challenges in the value chain of the commodity in question while at the same time taking advantage of new opportunities in its operating environment. There is also a need to safeguard the availability, accessibility and utilization of markets, resources and information.

\section{Conflict of interest}

The authors declare that there were no conflicts of interest in this study. They are independent university researchers who are not part of the platform under study.

\section{Acknowledgement}

The authors would like to thank Regional Universities Forum for Capacity Building in Agriculture (RUFORUM) and Germany Academic Exchange programme (DAAD) for supporting and financing research for this work. 
Creative Commons User License: CC BY-NC-ND

Abstracted by: EBSCOhost, Electronic Journals Service (EJS),

Google Scholar, Journal Seek, Scientific Commons,

Food and Agricultural Organization (FAO), CABI and Scopus

http://eoi.citefactor.org/10.11226/v23i3
Journal of Agricultural Extension

Vol. 23 (3) July, 2019

ISSN(e): 24086851; ISSN(Print); 1119944X

http://journal.aesonnigeria.org

http://www.ajol.info/index.php/jae

Email: editorinchief@aesonnigeria.org

\section{References}

Adekunle, A. A \& Fatunbi, A.O. (2012). Approaches for setting-up multi-stakeholder platforms for agricultural research and development. World Applied Sciences Journal 16(7): 981-988.

Andres, C., Mandloi, L. S. and Bhullar, G. S. (2016). Sustaining the supply of organic white gold. In Innovation Platforms for Agricultural Development. Evaluating the Mature Innovation Platforms Landscape, 133-150 (Eds I. Dror, J.-J. Cadilhon, M. Schut, M. Misiko and S. Maheshwari). London, UK: Routledge.

Ayele, S. A. (2012). "Enhancing Innovation in Livestock Value Chains through Networks: Lessons from Fodder Innovation Case Studies in Developing Countries." Science and Public Policy 39 (3): 333-346.

Cullen B, Josephine T, Katherine S, Zelalem L \& Alan D (2014). An analysis of power dynamics within innovation platforms for natural resource management, Innovation and Development, 4:2, 259-275, DOI: 10.1080/2157930X.2014.921274

Dimelu, M. U, Enwelu, I. A, Attah, C. P, \& Emodi, A. I. (2014). Enhancing Performance of Farmers' Cooperative in Rice Innovation System in Enugu State, Nigeria. Journal of Agricultural Extension. Vol.18 (2) December, 2014

Hermans F, Sartas M, van Schagen B, van Asten P, Schut M (2017). Social network analysis of multi-stakeholder platforms in agricultural research for development: Opportunities and constraints for innovation and scaling. PLoS ONE 12(2): e0169634.doi:10.1371/journal.pone.0169634.

Homann-Kee Tui, S., Adekunle, A. A., Lundy, M., Tucker, J., Birachi, E. A., Schut, M. \& Mundy, P. (2013). What are innovation platforms?

Jones, C., Hesterley, W., \& Borgatti, S. (1997). A General Theory of Network Governance: Exchange Conditions and Social Mechanisms. Academy of Management Review, 22, 911 - 945.

Kilelu, C. W., Klerkx, L., \& Leeuwis, C. (2013). Unravelling the role of innovation platforms in supporting co-evolution of innovation: Contributions and tensions in a smallholder dairy development programme. Agricultural Systems, 118, 65-77.

Krejcie, R. V, \& Morgan, D. W. (1970). Determining Sample Size for Research Activities Robert. Educational and Psychological Measurement, 38(1), 607-610. http://doi.org/10.1177/001316447003000308

Messmann, G., \& Mulder, R. H. (2012). Development of a measurement instrument for innovative work behaviour as a dynamic and context-bound construct. Human Resource Development International, 15(1), 43-59. Taylor \& Francis. Homepage:http://www.tandfonline.com/toc/rhrd20/15/1.

Saravanan, R. and Suchiradipta, B. (2017). Agricultural Innovation Systems: Fostering Convergence for Extension. MANAGE Bulletin 2 (2017), National Institute of Agricultural Extension Management, Hyderabad, India.

Sartas, M. (2018). Do Multi-Stakeholder Platforms Work? Contributions of MultiStakeholder Platforms to the Performance of Research for Development Interventions. A PhD thesis, Wageningen University, Wageningen, the Netherlands. DOI: https://doi.org/10.18174/459129 ISBN: 978-94-6343-507-9. 
Creative Commons User License: CC BY-NC-ND

Abstracted by: EBSCOhost, Electronic Journals Service (EJS), Google Scholar, Journal Seek, Scientific Commons,

Food and Agricultural Organization (FAO), CABI and Scopus

http://eoi.citefactor.org/10.11226/v23i3
Journal of Agricultural Extension

Vol. 23 (3) July, 2019

ISSN(e): 24086851; ISSN(Print); 1119944X

http://journal.aesonnigeria.org

http://www.ajol.info/index.php/jae

Email: editorinchief@aesonnigeria.org

Serena, C. (2018). Ten Steps in Scale Development and Reporting: A Guide for Researchers, Communication Methods and Measures, 12:1, 25-44, DOI: 10.1080/19312458.2017.1396583

Schut, M., Kamanda, J., Gramzow, A., Dubois, T., Stoian, D., Andersson, J.A., Dror, I. Sartas, M., Mur, R., Kassam, S., Brouwer, H. (2018). Innovation platforms in agricultural research for development: Ex-ante appraisal of the purposes and conditions under which innovation platforms can contribute to agricultural development outcomes. Experimental Agriculture, Jun: 1-22.

Schut, M., Rodenburg, J., Klerkx, L., van Ast, A., \& Bastiaans, L. (2014). Systems approaches to innovation in crop protection. A systematic literature review. Crop Protection, 56, 98-108.

Swaans, K., Puskur, R., Taye, H. and Haile, A.G. (2013). A monitoring and evaluation framework to assess the performance of innovation platforms in the context of livestock value chains. ILRI Discussion Paper 24. Nairobi, Kenya: International Livestock Research Institute.

Turyahikayo, W., Matsiko, F. B., Okiror, J. J., \& Buregyeya, M. (2017). Understanding actor innovation behavior: The application of network governance theory in agricultural innovation platforms. Journal of Agricultural Extension and Rural Development, 9(11), 247-254.

Uganda Bureau of Statistics [UBOS]. (2016). The National Population and Housing Census 2014 - Main Report, Kampala, Uganda 